\section{Eleanora Pantano}

is a Post-Doc at the Department of Mechanical, Energetic and Management Engineering at the University of Calabria, Italy and Eindhoven Technical University, The Netherlands.

Vincenzo Corvello is Assistant Professor at the Department of Mechanical, Energetic and Management Engineering at University of Calabria, Italy.

Keywords: social networks, usergenerated content, information management, organizational practices, customer experience

\section{Importance of online consumer comments}

Eleanora Pantano

Department of Mechanical,

Energetic and Management Engineering,

University of Calabria, Italy

Tel: + 00390984492235

E-mail: eleonora.pantano@unical.it

\section{The impact of experience on companies' reactions to negative comments on social networks}

\author{
Eleanora Pantano and Vincenzo Corvello \\ Received (in revised form): 6th November 2012
}

\begin{abstract}
Owing to the increasing adoption of social networks among consumers and the effect of their online negative reviews on firms' profitability, this paper explains research into possible strategies for replying to negative word-of-mouth (nWOM). On the basis of a study involving 237 firms, we examine how companies can react to nWOM communication and how their actions are influenced by experience with the social network. The results show the eight most frequent strategies adopted: discount coupon, post removal, request for post removal by consumer, sending another free product, product substitution, acceptance of consumer's request and providing excuses/ explanation, plus 'no reaction'. The results also correlate the number of fans and presence on Facebook to the type of reaction, with a significant difference among highly experienced firms and a significantly higher level of 'no reaction' among less experienced companies.

Journal of Direct, Data and Digital Marketing Practice (2013) 14, 214-223. doi:10.1057/dddmp.2013.3
\end{abstract}

\section{Introduction}

Due to the increasing adoption of social networks like Facebook, interacting with large communities of consumers has become easier for firms. This channel represents a valuable opportunity for organizations to gain knowledge of consumers' past experiences with their products, as well as their needs and preferences. ${ }^{1}$ In fact, there is wide availability of consumers' comments online, both negative and positive. The role of these comments has been largely studied with reference to their ability to influence other consumers. ${ }^{2}$ Their role as a source of knowledge for firms has been considered less often. In particular, there is a dearth of studies on the role of negative comments on social networks from the organizations' point of view. In this paper, we specifically focus on the role of negative reviews on a company's subsequent actions, by investigating to what extent the firm's experience with the social network affects this reaction.

The management of interactions with users on social networks is becoming more and more important for firms. The high number of 


\section{Role of electronic word-of-mouth communication (eWOM)}

\section{Experience changes WOM strategy}

users, comments, discussions and reviews on a brands' Facebook page is an indicator of popularity of the brand, the product or the firm itself. ${ }^{3,4}$ Moreover, many organizations use online interaction to target potential customers, identify market trends and propose customized marketing strategies. ${ }^{5}$ In fact, other studies have highlighted the opportunities offered by Facebook for implementing loyalty programmes ${ }^{6}$ and for influencing their purchasing decisions. ${ }^{4,7,8}$

Due to their influence on consumer behaviour, positive comments are more desirable for spreading a positive image among clients. As a consequence, firms try to involve consumers in online discussions and to influence their interactions and comments by adopting different viral marketing strategies. ${ }^{9,10}$ For this reason, some recent studies have focused on best practices for influencing online reviews in order to increase product sales. ${ }^{11}$ As a consequence, according to the surveyed literature, use of social networks is able to influence the firm's market orientation. $^{12}$

Users' comments online are part of electronic word-of-mouth (eWOM), an informal way of communicating among individuals through digital channels. Comments on social networks can be used by organizations to improve their products and services and as a valuable source of information. More specifically, negative comments provide information on limits and opportunities for improvement of products or services. In this paper, we refer to negative comments on social network as negative word-of-mouth (nWOM). While eWOM has been extensively studied in previous literature, ${ }^{1,13-16} \mathrm{nWOM}$ is still an under-researched field.

As with positive comments, firms can chose among various possible reactions to nWOM. Some of these are oriented at reducing the negative impact by making such comments less visible (ie, hiding the comment or asking the customer to delete the post). Others are aimed at demonstrating that the firm is willing and able to correct possible errors (ie, replying with apologies, giving an explanation or a reimbursement). Several factors can influence a firm's choice in reacting to nWOM: for example, organizational culture, the characteristics of the customer and the marketing strategy of the firm.

As a company grows more experienced with the use of social media, it is likely that its approach to managing nWOM will change. In fact, experience influences different activities such as problem solving, information processing and forming opinion at the individual level. ${ }^{17}$ From a consumers' point of view, experienced social media users (in terms of people who make extensive use of the social medium) are more willing to be influenced in their purchasing decision. ${ }^{1}$ Hence, it is possible to argue that experience with the social network also influences organizational behaviour.

The aim of this paper is to understand what are the possible reactions to negative online posts and how experience with the social network influences this reaction. To achieve this goal, we conducted a content analysis that involved 237 subjects from Italian firms. 
User-generated content

\section{Rating products based on reviews}

\section{Sharing negative experiences}

\author{
Negative forms of \\ eWOM
}

The first part of the paper is devoted to an analysis of the literature on user-generated content (UGC) and eWOM supported by social networks; the second part focuses on a qualitative analysis involving 237 firms to gain an understanding of the practices adopted by firms in reaction to nWOM and the impact of their experience with social networks. Future directions for satisfying (online) consumers' expectations follow.

\section{Theoretical background}

Social networks are a popular way for sharing and diffusing knowledge at huge scale. ${ }^{18}$ With the increasing adoption of social networks, the role of consumers is not to seek information passively, but to actively share information with other users through online platforms in the form of rich textual comments (reviews, discussion, etc). ${ }^{19,20}$ These opinions form the so-called UGC. Previous studies on information propagation found that these types of content are able to increase their popularity over many years. ${ }^{18}$ Since these comments contain data on users' interests, opinions and behaviours, they can be exploited as powerful sources of data on market trends and also to set more efficient recommender systems. ${ }^{20,21}$ On the other hand, they are a data source for consumers who can obtain more information on products and firms as part of their purchasing decision process. ${ }^{22}$ Furthermore, consumers' interest and trust in online consumer-generated product information is greater compared to content posted by vendors. ${ }^{8,14}$

This knowledge-sharing among users is a form of eWOM. Given the rapid growth of this phenomenon, an increasing number of third-party infomediaries has begun to invite consumers to rate the products or services they have consumed and then offer an aggregated rating of the item. ${ }^{23}$ This process is quicker and more efficient than traditional word-of-mouth based on face-to-face messages, which is not able to collect all consumers' impressions and provide a final product evaluation.

Since each user is able to post a review, there is a great amount of information, albeit with negative consequences relating to 'information overload $^{10}$ as well as to the quality of available comments, which varies from high to low quality and might also include spams and insults, etc. ${ }^{24}$

Although the number of positive reviews is greater than negative ones $^{25}$ and consumers tend to post positive comments - mainly due to the sense of belonging to the community and enjoyment of helping others $^{13}$ — people who are dissatisfied with a service or product are more willing to share their negative experience with other potential consumers. ${ }^{1,26}$ This situation is not dissimilar to offline word-of-mouth communication. ${ }^{27}$ Negative reviews tend to relate disappointing experiences with a certain product or a service, usually referring to some expectations not being met, which could damage the firm's reputation. ${ }^{26,28}$

Past research has furthermore showed the greater influence of nWOM compared to positive comments. ${ }^{16}$ In fact, consumers 


\section{Mitigating negative comments}

\section{Brands' reactions to negative WOM (nWOM)}

\section{Changing responses to negative comments}

usually pay more attention to negative reviews than to positive ones and consider negative ones more informative. ${ }^{26,29}$ On the one hand, a negative review has negative consequences for sales, on the other it can hinder other (positive) posts or solicit other negative comments. ${ }^{30}$

Despite the negative effects of this kind of comment, their absence might indicate a lack of discussion among users and result in an environment not capable of attracting users ${ }^{30}$ and induce managers to underestimate the impact of nWOM. ${ }^{31}$ Since the $n W O M$ provides valuable information for firms to improve their relationship with consumers, ${ }^{32}$ organizations need to exploit the knowledge made available by negative comments on social networks and to reduce the negative impact of these on their reputation.

Hence, understanding the practices that firms use for mitigating the negative consequences of nWOM and to exploiting the knowledge emerging from nWOM becomes an important factor for the business success. For instance, some authors suggest that creating strong ties with customers might reduce their intention to spread nWOM. ${ }^{33}$

To date, studies have largely focused on the analysis of the consumer perspective towards eWOM and UGC, in terms of motivation to post online, information searching and sharing process, and their decision-making process, without taking into account the organizational perspective. Indeed, there is still a gap in the literature concerning firms' behaviours, perceptions and reaction to customer reviews, especially in the context of nWOM. ${ }^{34}$

Not all organizations will react to nWOM with the same type of action. Some organizations react with explanations, others with apologies or excuses. For instance, Munzel and colleagues ${ }^{34}$ have found that apologies following a negative comment on a social network improve customers' opinions of the firm. Other possible reactions can be removing the post, ignoring or even manipulating it, even though research suggests that ignoring, removing or manipulating the comment can have a negative effect on the firms' reputation. ${ }^{35}$

Other research on social media suggests that, just as with individuals, ${ }^{36}$ organizational experience with using social media also influences behaviour. For this reason it is expected that, as the experience of a company with Facebook increases, the way it reacts to negative reviews changes. In particular, previous studies highlighted how experience with technology influences adoption and usage behaviour. ${ }^{17}$ For instance, Jones and colleagues observe that as experience with Customer Relationship Management increases, the procedures and routines adopted by salespersons in firms change. ${ }^{37}$ Dellarocas ${ }^{35}$ observes that some firms manipulate online comments and that their manipulation practices evolve in time. Wolk and Skiera ${ }^{38}$ found that sales practices of firms using e-commerce channels change with their experience with the technology. This influence of organizational experience with social networks on their reaction to nWOM has not been addressed in previous studies. 


\section{Qualitative analysis among brands}

\section{Results from content analysis}

\section{Research}

This research aims at investigating how firms' reactions to negative consumer reviews and comments change when the experience of the organization with Facebook increases. We consider experience as a factor that affects an individual's or an organization's approach to performing a certain task and/or using a particular system. ${ }^{17}$ In this study, experience has been measured through two variables: (i) in terms of months of presence on the social network (the longer a firm's page has been on Facebook, the higher the experience of the firm with managing customers' comments); (ii) in terms of number of fans (the larger the community of fans, the higher the opportunity for interaction and, as a consequence, the potential experience in interacting with the customers).

The research involved 237 subjects in different firms, recruited in Italy between July and September 2012. Respondents were employees responsible for the management of the company fan page on Facebook. Table 1 summarizes these firms' characteristics.

Each interview has been coded and loaded through the MaxQda software for the content analysis. This investigation is first based on frequency analysis, in order to understand the value, the importance and the intensity of the possible variables. ${ }^{39}$ As scale of counting, we consider single words for describing the most frequent firms' reaction. Table 2 describes the main strategies undertaken by firms for replying to negative comments, with related frequency and percentage.

This analysis is not sufficient on its own, ${ }^{39}$ so we also conducted a contingent analysis based on the evaluation of association structures between the various codes that occurred in each interview, inferred by means of the codes that occur together.

Analysis was carried out on the codes referring to behaviours, length of presence on the social network (Table 3) and number of fans (Table 4). (As more than one behaviour could be named by respondents, totals sum to more than 100 per cent in each case.)

Table 1: Profile of firms researched

\begin{tabular}{|c|c|}
\hline \multicolumn{2}{|c|}{ Presence on web 2.0 (Facebook, Twitter, etc) } \\
\hline Less than 1 month & $4 \%$ \\
\hline Between 1 month and 1 year & $32 \%$ \\
\hline More than 1 year & $64 \%$ \\
\hline \multicolumn{2}{|l|}{ Number of fans } \\
\hline Less than 1,000 & $39 \%$ \\
\hline Between 1,001 and 9,999 & $43 \%$ \\
\hline More than 10,000 & $18 \%$ \\
\hline \multicolumn{2}{|l|}{ Frequency of nWOM } \\
\hline Never & $28 \%$ \\
\hline Rarely & $46 \%$ \\
\hline Very often & $26 \%$ \\
\hline \multicolumn{2}{|l|}{ Frequency of reaction to $n W O M$} \\
\hline Never & $13 \%$ \\
\hline Rarely & $26 \%$ \\
\hline Very often & $41 \%$ \\
\hline
\end{tabular}


Table 2: Main strategies for replying to nWOM

\begin{tabular}{lcc}
\hline Reaction & Frequency & Percentage \\
\hline Excuses/Explanation & 141 & 59 \\
Accepting consumer's request & 40 & 17 \\
No reaction & 30 & 13 \\
Product substitution & 15 & 6 \\
Free product & 10 & 4 \\
Post removal & 4 & 2 \\
Discount coupon & 2 & 1 \\
Request to revise post & 1 & 0 \\
\hline
\end{tabular}

Table 3: Behaviour by length of presence on social network

\begin{tabular}{lcc}
\hline & Less than 1 year (76 firms) & More than 1 year (152 firms) \\
\hline Excuses/Explanation (\%) & 60 & 61 \\
No reaction (\%) & 21 & 8 \\
Accepting consumer's request (\%) & 14 & 16 \\
Product substitution (\%) & 6 & 6 \\
Post removal (\%) & 3 & 0.1 \\
Free product (\%) & 3 & 6 \\
Request to revise post (\%) & 0.1 & 0 \\
Discount coupon (\%) & 0 & 0.1 \\
\hline
\end{tabular}

Table 4: Behaviour by number of fans

\begin{tabular}{lccc}
\hline & $\begin{array}{c}\text { Less than 1,000 } \\
\text { fans (91 firms) }\end{array}$ & $\begin{array}{c}\text { Between 1,000 and } \\
10,000 \text { (100 firms) }\end{array}$ & $\begin{array}{c}\text { More than 10,000 } \\
\text { (44 firms) }\end{array}$ \\
\hline Excuses/Explanation (\%) & 51 & 59 & 82 \\
Accepting consumer's & 21 & 16 & 78 \\
$\quad$ request (\%) & 14 & 12 & 2 \\
No reaction (\%) & 3 & 0 & 7 \\
Post removal (\%) & 2 & 4 & 0 \\
Free product (\%) & 1 & 0 & 0 \\
Request to revise post (\%) & 0 & 2 & 7 \\
Discount coupon (\%) & & & \\
\hline
\end{tabular}

\section{Effective reactions to nWOM}

\section{Discussions}

The aim of this study is to understand if firms' experience with social networks and with negative consumer comments influences their reactions when they receive a negative comment from a fan.

The content analysis we conducted produced a list of possible reactions to negative comments adopted in the past, including also the lack of reaction. The absolute and relative frequencies of these reactions were considered. A noteworthy finding is that 'Excuse/ explanation' is the most frequent reaction, whereas the second is 'Accepting consumer's request'. When adopting these reactions, a firm recognizes that an error has been made and tries to correct its behaviour. We call these 'positive reactions'. The likely goal of the firm is to improve the opinion of customers by proving that their 


\section{Changing reactions to nWOM}

comments are taken into consideration and the organization is willing to satisfy their needs.

'No reaction' ranks only third and, while 'negative reactions' like 'Post remoal' or 'Request to revise post' were found, these are less frequent than reactions aimed at mitigating the complaints. When choosing this kind of reaction, a firm is aiming to reduce the visibility of the negative comment, thus avoiding its impact on the firm reputation.

Although frequency attributed to positive reactions could be amplified by response bias (ie respondents answer questions in the way they think the questioner wants them to answer), the analysis of the data shows clearly that the respondents consider it important to take into account their customers' negative comments. These results are consistent with previous literature that underlines how several different reactions to $\mathrm{nWOM}$ are possible and that reactions aimed at reducing customer dissatisfaction are a proper way to manage eWOM. ${ }^{34}$

We analysed how the frequency of various types of reactions changed with experience. ${ }^{35,37,38}$ As explained in the 'Research' section, experience was measured through two distinct factors: (1) the time elapsed since the firm started its presence on Facebook (by creating a profile or page); (2) the number of fans.

A clear trend is visible when analysing data according to the dimensions 'time on Facebook' and 'number of fans' - in both cases, the frequency of 'positive reactions' like excuses, acceptance of customers' request or product substitution tends to increase in the groups associated with greater experience (more time on Facebook and more fans). On the contrary, negative reactions (including 'no reaction') tend to become less frequent in the groups associated with a greater experience. For instance, while the 21 per cent of the firms with less than 1 year on Facebook stated that they received negative comments in the past but did not react, only 8 per cent of firms with more than 1 year of experience said the same. The frequency of cases in which customers' requests were accepted increases from 14 per cent in the first group (less than 1 year on Facebook) to 16 per cent (more than 1 year).

Similarly the frequency of the 'excuses/explanation code' increases from 51 per cent in the group of firms with less than 1,000 fans to 82 per cent in the group with more than 10,000 fans, while the "no reaction' code decreases from 14 per cent in the group of firms with less than 1,000 fans to 7 per cent in the group with more than 10,000 fans. These results suggest that as experience with Facebook increases, they tend to react more positively to the negative comments of customers.

Firms learn by experience how to interact with customers on the social network. Previous literature suggests that negative comments can damage a firm's reputation. ${ }^{26,28}$ Our findings suggest that positive reactions to these are more likely to be chosen by experienced firms. It is likely, then, that in time positive reactions have been found more 


\section{Investigating nWOM from the brand's point of view}

\section{Learning from experience to pay attention}

\section{Future directions for nWOM research}

capable of reducing the damaging effects of nWOM than negative ones. ${ }^{34,35}$

Our findings suggest that firms with less experience on Facebook tend to underestimate the opportunity offered by consumers' comments, in particular negative ones. Facebook is not only a channel for advertising and diffusing the brand image, but also a channel for communicating with customers and evaluating their experience with the firm.

\section{Conclusions and future works}

The importance of negative reviews as a powerful resource for organizations to evaluate and improve their current strategies has been recognized in past studies. ${ }^{32}$ Furthermore, from a consumers' point of view, the absence of nWOM reduces the attractiveness of the channel. ${ }^{30}$ Hence, firms are forced to take into account the presence of nWOM. Moreover, they can exploit it to improve business profitability.

The main contribution of this study lies in researching the effects of nWOM from an organizational point of view. Secondly, our findings show to what extent firm's reactions to negative reviews change with experience with the social network, as anticipated by Yoon ${ }^{17}$ concerning experience with technology. We found that as experience with Facebook grows, firms modify their behaviour, paying more attention to consumers' complaints. Thus the actions undertaken by firms with no or limited experience with the social network differ from the ones of experienced firms.

Behaviours based on the acceptance of customers' critiques (ie excuses) are more common among experienced organizations, compared to the large number of less-experienced firms that ignore consumers' complaints. Firms learn from experience the importance of paying attention to complaints, especially for avoiding the contagion effect of eWOM. For this reason, instead of removing negative reviews or requesting consumers to delete them, firms could invite their customers to add comments. Managers should continually invest in activities that strengthen relationships with customers online and exploit the benefits of eWOM to enhance their image. ${ }^{33}$ To achieve this goal, new web-based customer relationship management strategies should be developed to reply to the continuing evolution of technology. ${ }^{40}$

Although this study provides interesting results, it presents some limitations. First, the study does not question the truthfulness of the respondents' answers, considering that they could have a different perception of consumers' nWOM or have manipulated answers to preserve their reputation. For instance, they could have declared a lower number of online complaints than was actually experienced. Secondly, this study considers the experience of firms with the social network, but it does not take into account other factors that could influence the capability of the firm to reply effectively to consumers' requests. Therefore, further researches should test the effects of parameters like turnover and size. 


\section{桨. Pantano and Corvello}

\section{References and Notes}

1. Di Pietro, L. and Pantano, E. (2012) 'An empirical investigation of social network influence on consumer purchasing decision: The case of Facebook', Journal of Direct, Data and Digital Marketing Practice, Vol. 14, No. 1, pp. 18-29.

2. Perrigot, R., Kacker, M., Basset, G. and Cliquet, G. (2012) 'Antecedents of early adoption and use of social media networks for stakeholder', Journal of Small Business Management, Vol. 50, No. 4, pp. 539-565.

3. Plangger, K. (2012) 'The power of popularity: How the size of a virtual community adds to firm value', Journal of Public Affairs, Vol. 12, No. 2, pp. 145-153.

4. Pantano, E., Tavernise, A. and Viassone, M. (2010) 'Consumer perception of computer-mediated communication in a social network', in Proceedings of the 4th International Conference on New Trends in Information Science and Service Science (NISS2010), IEEE, Gyeongju, Korea, pp. 609-614.

5. Hogg, T. (2009) 'Inferring preference correlations from social networks', Electronic Commerce Research and Applications, Vol. 9, No. 1, pp. 29-37.

6. Gummerus, J., Liljander, V., Weman, E. and Pihlstrom, M. (2012) 'Customer engagement in a Facebook brand community', Management Research Review, Vol. 35, No. 9, pp. 857-877.

7. Hinz, O., Schulze, C. and Takac, C. (in press) 'New product adoption in social networks: Why direction matters', Journal of Business Research.

8. Archak, N., Ghose, A. and Ipeirotis, P. (2007) 'Show me the money!: Deriving the pricing power of product features by mining consumer reviews', in Proceedings of the 13th International Conference on Knowledge Discovery and Data Mining, ACM, San Jose, CA, USA, pp. 56-65.

9. Aral, S. and Walker, D. (2011) 'Creating social contagion through viral product design: A randomised trial of peer influence in networks', Management Science, Vol. 57, No. 9, pp. 1623-1639.

10. O'Mahony, M.P. and Smyth, B. (2010) 'A classification-based review recommender', Knowledge-based Systems, Vol. 23, No. 4, pp. 323-329.

11. Hu, N., Bose, I., Koh, N.S. and Liu, L. (2012) 'Manipulation of online reviews: An analysis of ratings, readability and sentiments', Decision Support Systems, Vol. 52, No. 3, pp. 674-684.

12. Assis-Dorr, H., Palacios-Marques, D. and Merigo, J.M. (2012) 'Social networking as an enabler of change in entrepreneurial Brazilian firms', Journal of Organizational Change Management, Vol. 25, No. 5, pp. 699-708.

13. Cheung, C.M.K. and Lee, M.K.O. (2012) 'What drives consumers to spread electronic word of mouth in online consumer-opinion platforms', Decision Support Systems, Vol. 53, No. 1, pp. 218-225.

14. Dou, X., Walden, J.A., Lee, S. and Lee, J.Y. (2012) 'Does source matter? Examining source effects in online product reviews', Computers in Human Behavior, Vol. 28, No. 5, pp. $1555-1563$.

15. Moe, W.W. and Schweidel, D.A. (2012) 'Online product opinions: Incidence, evaluation, and evolution', Marketing Science, Vol. 31, No. 3, pp. 372-386.

16. Park, C. and Lee, T.M. (2009) 'Information direction, website reputation and eWOM effect: A moderating role of product type', Journal of Business Research, Vol. 62, No. 1, pp. 61-67.

17. Yoon, C. (2010) 'Antecedents of customer satisfaction with online banking in China: The effects of experience', Computers in Human Behaviour, Vol. 26, No. 6, pp. 1296-1304.

18. Cha, M., Mislove, A. and Gummadi, K.P. (2009) 'A measurement-driven analysis of information propagation in the Flickr social network', in Proceedings of the 18th World Wide Web Conference Committee (IW3C2), ACM, Madrid, Spain, pp. 721-730.

19. Tirunillai, S. and Tellis, G.J. (2012) 'Does chatter really matter? Dynamics of user-generate content and stock performance', Marketing Science, Vol. 31, No. 2, pp. 198-215.

20. Messenger, A. and Whittle, J. (2011) 'Recommendations based on user-generated comments in social media', in Proceedings of International Conference on Privacy, Security, Risk and Trust and International Conference on Social Computing; IEEE, Boston, MA, pp. 505-508. 
21. Pantano, E. and Corvello, V. (2010) 'Digital contents management for improving consumers' experience', International Journal of Digital Content Technology and Its Applications, Vol. 4, No. 7 , pp. $8-10$.

22. Archak, N., Ghose, A. and Ipeirotis, P. (2011) 'Deriving the pricing power of product features by mining consumer reviews', Management Science, Vol. 57, No. 8, pp. 1485-1509.

23. Qui, L., Pang, J. and Lim, K.H. (2012) 'Effects of conflicting aggregated rating on eWOM review credibility and diagnosticity: The moderating role of review valence', Decision Support Systems, Vol. 54, No. 1, pp. 631-643.

24. Agichtein, E., Castillo, C., Donato, D., Gionis, A. and Mishne, G. (2008) 'Finding highquality content in social media', in Proceedings of the International Conference on Web Search and Web Data Mining, ACM, Palo Alto, CS, pp. 183-194.

25. East, R., Hammond, K. and Wright, M. (2007) 'The relative incidence of positive and negative word of mouth: A multi-category study', International Journal of Research in Marketing, Vol. 24, No. 2, pp. 175-184.

26. Bambauer-Sachse, S. and Mangold, S. (2011) 'Brand equity dilution through negative online word-of-mouth communication', Journal of Retailing and Consumer Services, Vol. 18, No. 1, pp. $38-45$.

27. Anderson, E.W. (1998) 'Customer satisfaction and word of mouth', Journal of Service Research, Vol. 1, No. 1, pp. 5-17.

28. Vasquez, C. (2011) 'Complaints online: The case of TripAdvisor', Journal of Pragmatics, Vol. 43, No. 6, pp. 1707-1717.

29. Sen, S. and Lerman, D. (2007) 'An examination into negative consumer reviews on the web', Journal of Interactive Marketing, Vol. 21, No. 4, pp. 76-94.

30. Sood, S.O., Churchill, E.F. and Antin, J. (2012) 'Automatic identification of personal insults on social news sites', Journal of the American Society for Information Science and Technology, Vol. 63, No. 2, pp. 270-285.

31. Amini, M., Wakolbinger, T., Racer, M. and Nejad, M.G. (2012) 'Alternative supply chain production-sales policies for new product diffusion: An agent-based modelling and simulation approach', European Journal of Operational Research, Vol. 216, No. 2, pp. 301-311.

32. Schmallegger, D. and Carson, D. (2008) 'Blogs in tourism: Changing approaches to information exchange', Journal of Vacation Marketing, Vol. 14, No. 2, pp. 99-110.

33. Yang, W. and Mattila, A.S. (2012) 'The role of tie strength on consumer dissatisfaction responses', International Journal of Hospitality Management, Vol. 31, No. 2, pp. 399-404.

34. Munzel, A., Jahn, B. and Kunz, W.H. (2012) 'The power of saying sorry- insights on customer service in new media online channels', in Proceedings of the 12th International Research Conference in Service Managements, 29 May - 1 June, Le Londe les Maures, France.

35. Dellarocas, C. (2006) 'Strategic manipulation of internet opinion forums', Management Science, Vol. 52, No. 10, pp. 1577-1593.

36. Di Pietro, L., Di Virgilio, L. and Pantano, E. (2012) 'Social network for the choice of tourist destination: Attitude and behavioural intention', Journal of Hospitality and Tourism Technology, Vol. 3, No. 1, pp. 60-76.

37. Jones, E., Brown, S.P., Zoltners, A.A. and Weitz, B.A. (2005) 'The changing environment of selling and sales management', Journal of Personal Selling \& Sales Management, Vol. 25, No. 2, pp. 105-111.

38. Wolk, A. and Skiera, B. (2009) 'Antecedents and consequences of internet channel performance', Journal of Retailing and Consumer Services, Vol. 16, No. 3, pp. 163-173.

39. Bos, W. and Tarnai, C. (1998) 'Content analysis in empirical social research', International Journal of Educational Research, Vol. 31, No. 8, pp. 659-671.

40. Corvello, V. and Migliarese, P. (2007) 'Virtual forms for the organisation of production: A comparative analysis', International Journal of Production Economics, Vol. 110, No. 1-2, pp. $5-15$. 